\title{
NEITHER GENOTYPE NOR THE GASTRIC COLONIZATION SITE OF Helicobacter pylori ARE PREDICTIVE FACTORS FOR THE DEVELOPMENT OF EROSIVE ESOPHAGITIS IN PATIENTS WITH PEPTIC ULCER DISEASE, 1 YEAR AFTER ERADICATION
}

\author{
Carlos Alexandre Gonçalves BATISTA, Fernando Marcuz SILVA, Ricardo Correa BARBUTI, \\ Jaime Natan EISIG, Rejane MATTAR and Tomás NAVARRO-RODRIGUEZ
}

\begin{abstract}
Context - Whether Helicobacter pylori infection is a protective or predisposing factor for the development of gastroesophageal reflux disease remains controversial. The most virulent strains, such as those expressing the cytotoxin-associated gene A (CagA), and the site of gastric colonization have been correlated with the prevention or development of esophagitis. Aim - To determine the incidence of erosive esophagitis following eradication of $H$. pylori in patients with peptic ulcer disease and to evaluate the association of erosive esophagitis with virulent strains of $\mathrm{H}$. pylori and the site of gastric colonization. Methods - Triple therapy with lansoprazole, amoxicillin and clarithromycin was administered to 159 patients with peptic ulcer disease. Endoscopy, histopathology, urease and carbon-14 urea breath tests were performed prior to treatment, at 3 months and 1 year following treatment. Genotyping of $H$. pylori strains using polymerase chain reaction was performed separately on samples from the corpus and antrum. Results - One year after treatment, 148 successfully treated patients were reevaluated. Twenty-eight patients (19\%) had erosive esophagitis, classified as Los Angeles grade A in 24 and B in 4. The samples taken from the corpus were CagA-positive in 18 patients (64\%), while the samples taken from the antrum were CagA-positive in 21 patients (75\%). Conclusions - The incidence of erosive esophagitis in peptic ulcer patients who had their H. pylori eradicated was $19 \%$. No correlation was found between the gastric site colonized by $H$. pylori or strains expressing $\operatorname{CagA}$ and the prevention or development of erosive esophagitis in patients with peptic ulcer disease, 1 year after infection eradication.
\end{abstract}

HEADINGS - Helicobacter pylori. Peptic ulcer. Esophagitis.

\section{INTRODUCTION}

Helicobacter pylori infection is highly prevalent worldwide; its incidence rate varies in accordance with the geographical region studied and the age and socioeconomic conditions of infected individuals ${ }^{(21,33,40)}$. Around $50 \%$ of the population worldwide is estimated to be infected ${ }^{(6)}$; however, only a small percentage of colonized individuals will develop a pathology related to the infection; for example, only $10 \%-20 \%$ will develop a gastric and/or duodenal ulcer ${ }^{(15)}$.

H. pylori is known to alter gastric acid secretion, consequently affecting the physiopathology of gastroduodenal ulcer disease ${ }^{(11)}$ and gastroesophageal reflux disease (GERD) $)^{(7)}$. The relationship between peptic ulcers and $H$. pylori has been well-established in the literature ${ }^{(30)}$. The same cannot be said with respect to its effect on the pathogenesis of GERD, although it has been proposed a complex interaction between them; however, data remain sparse and further studies must be carried out before this hypothesis can be confirmed ${ }^{(25,29)}$. The different ways in which $H$. pylori infection evolves may be explained by the response of the host and the different strains of the bacterium. The most aggressive strains, for example those expressing the cytotoxin-associated gene A ( $\operatorname{Cag} \mathrm{A})$, have been more frequently linked to the pathologies associated with this bacterium ${ }^{(2)}$. 
Studies investigating the participation of $H$. pylori in the physiopathology of GERD in patients with peptic ulcers were initiated following the pioneering work of LABENZ et al. ${ }^{(17)}$, who studied $H$. pylori-positive duodenal ulcers patients. The authors reported a higher rate of esophagitis in patients who had their $H$. pylori eradicated compared to the group in which the infection had continued. Following this first study, other trials were carried out, either confirming LABENZ' work $^{(8,9,14)}$ or reporting contradictory results ${ }^{(1,24,36,38,41,42,44)}$.

Another focus of investigation has been the relation between the severity of GERD and H. pylori infection. Some investigators have suggested that $H$. pylori-positive patients have a lower incidence of GERD and less severe esophagitis when compared to uninfected patients ${ }^{(35)}$. A relevant study published by VICARI et al. ${ }^{(39)}$ showed that the more aggressive the strains of $H$. pylori (CagA-positive), the less intense were the esophagitis and vice-versa.

In many studies, $H$. pylori strains were isolated in the antral region of the stomach. Recently paper reported the infection with the CagA-positive strains of the bacterium promoted epithelial proliferation ${ }^{(3)}$ that was directly and significantly correlated with inflammation in the colonized area of the stomach.

A meta-analysis summarizing the results of 14 case-control studies and 10 clinical trials confirmed that $H$. pylori-negative status is associated with a significant increased risk of GERD ${ }^{(5)}$. This finding may also be explained by the fact that individuals with a predominantly antral infection are expected to have greater gastric acid secretion and are, therefore, more likely to develop a duodenal ulcer and/or GERD. On the other hand, gastric acid secretion would be lower in individuals in whom the infection is predominantly in the gastric corpus, which may reduce the risk of GERD.

Studies on the pathogenesis of $H$. pylori are of interest in Brazil, where prevalence of the infection is high $^{(43)}$, a common characteristic in developing countries, although the prevalence of GERD is similar to that found in the first world ${ }^{(27)}$.

\section{Objective}

The objective of this study was to evaluate the incidence of erosive esophagitis in patients with peptic ulcers, 1 year after eradication of $H$. pylori, taking into consideration the effect of strains expressing $\operatorname{CagA}$ and the gastric site of colonization: the gastric antrum or corpus.

\section{METHODS}

\section{Population}

One hundred and fifty nine patients receiving care at the Gastroenterology Outpatient Department of the University of São Paulo, "Hospital das Clínicas", São Paulo, SP, Brazil, with a peptic ulcer diagnosed at upper digestive endoscopy and $H$. pylori status confirmed by at least two of three tests (urease, histopathology and carbon-14 urea breath test) were included in this study.

Exclusion criteria consisted of: patients who had been in use of nonsteroidal anti-inflammatory drugs (NSAIDs) or antibiotics, either chronically or in the 4 weeks that preceded inclusion in the study; patients with complicated peptic ulcers, erosive esophagitis, Barrett's esophagus, cancer of the digestive tract, pregnant or breast-feeding women, patients with a history of surgery of the esophagus, stomach, duodenum or gall bladder; those who had undergone previous treatment for H. pylori and patients with chronic diseases such as diabetes, neuropathies, hypo- or hyperthyroidism, kidney failure and collagenosis.

All patients recruited to the study gave their written, informed consent. The study protocol was approved by the Internal Review Board of the institution.

\section{Endoscopy and biopsies}

Upper digestive tract endoscopy was performed to confirm diagnosis of a peptic ulcer and to collect samples for confirmation of $\mathrm{H}$. pylori colonization. Four fragments of gastric mucosa were collected, two from the antrum and two from the corpus, one sample from each site for histopathological investigation and the other for urease test. The fragments used in the urease test were sent for genotyping whenever the presence of $H$. pylori was detected. Endoscopic diagnosis and grading of reflux esophagitis were based on the Los Angeles classification ${ }^{(20)}$.

\section{Genotyping}

DNA was extracted from gastric biopsy samples with positive rapid urease tests using a salting out procedure ${ }^{(26)}$. Polymerase chain reaction (PCR) was performed according to a previously reported method ${ }^{(23)}$ using a thermal cycler $(2400$ Gene Amp PCR system, PerkinElmer, Branchburg, NJ, USA). PCR conditions for $\mathrm{CagA}$ amplification consisted of initial denaturation at $94^{\circ} \mathrm{C}$ for 5 minutes followed by 27 cycles of denaturation at $94^{\circ} \mathrm{C}$ for 30 seconds, annealing at $53^{\circ} \mathrm{C}$ for 30 seconds and extension at $72^{\circ} \mathrm{C}$ for 30 seconds ${ }^{(4)}$. The final extension at $72^{\circ} \mathrm{C}$ was performed for 7 minutes. One set of primers (P1 and P2) that amplifies the $26 \mathrm{kDa}$ antigen gene present in all strains of $H$. pylori was then used according to the following conditions: initial denaturation at $94^{\circ} \mathrm{C}$ for 5 minutes followed by 40 cycles of denaturation at $93^{\circ} \mathrm{C}$ for 1 minute, annealing at $57^{\circ} \mathrm{C}$ for 2 minutes and extension at $70^{\circ} \mathrm{C}$ for 2 minutes ${ }^{(10)}$.

\section{Urea breath test}

Carbon-14 (14C) urea breath test was carried out to diagnose $H$. pylori and to evaluate its eradication, according to a previously described technique ${ }^{(22)}$.

\section{Treatment and follow-up}

All patients received a 7-day therapeutic regimen consisted of $30 \mathrm{mg}$ lansoprazole, $500 \mathrm{mg}$ clarithromycin and $1 \mathrm{~g}$ amoxicillin, BID. After treatment, neither proton-pump inhibitors nor $\mathrm{H}_{2}$-receptor antagonists were permitted; however, patients were allowed to take antacids and/or prokinetics during the entire study period.

The patients were reevaluated 3 months after the eradication treatment, when a second upper digestive endoscopy was performed; two samples were collected from the gastric 
antrum and the corpus for urease test and histopathology. Additionally, the patients were submitted to a urea breath test. They were considered cured of the infection when all tests were negative. One year after treatment, the remaining patients were reevaluated by undergoing another upper endoscopy during which the presence of $H$. pylori was investigated.

\section{Statistical analysis}

Quantitative variables were described as means and standard deviations, range, and absolute and relative frequencies. Comparison between the groups of interest with respect to the qualitative variables was carried out using the chi-square test. Significance level was established as $P<0.05$.

\section{RESULTS}

Of the 159 patients admitted to the study, the $H$. pylori eradication failed in 11, which resulted in an eradication rate of $93 \%$ (per protocol). One year after treatment 148 patients were available for analysis. The mean age of these patients was 46.5 years with median 46 years (range 18-82 years), 96 $(64.9 \%)$ were female. At baseline upper endoscopy, 106 patients $(71.6 \%)$ had duodenal and $26(17.6 \%)$ had gastric ulcers (Table 1). The gastric corpus samples were $H$. pylori CagA-positive in 91 patients $(61.5 \%)$, while the samples taken from the antrum were H. pylori CagA-positive in 103 patients (69.6\%) (Table 2).

TABLE 1. Demographic and type of ulcer data of the sample of patients that concluded the study (148 patients)

\begin{tabular}{llc}
\hline Age & Mean & 46.5 years \\
& Median & 46 years \\
Gender & Range & $18-82$ years \\
Type of ulcer & Female & $96(64.9 \%)$ \\
& Gastric & $26(17.6 \%)$ \\
& Duodenal & $106(71.6 \%)$ \\
& Gastric + duodenal & $16(10.8 \%)$ \\
\hline
\end{tabular}

TABLE 2. CagA status according to gastric site

\begin{tabular}{lcc}
\hline Gastric site & CagA-positive & CagA-negative \\
\hline Corpus & $91(61.5 \%)$ & $57(39 \%)$ \\
Antrum & $103(69.6 \%)$ & $45(30 \%)$ \\
\hline$P=0.14$ & &
\end{tabular}

Upper endoscopy carried out 1 year after $H$. pylori eradication revealed erosive esophagitis in 28 patients $(19 \%)$. In these patients, gastric mucosal samples taken from the corpus were $H$. pylori CagA-positive in 18 patients $(64 \%)$ and CagA-negative in $10(36 \%)$ (Table 3).

TABLE 3. CagA status and intensity of erosive esophagitis 1 year after eradication

\begin{tabular}{lccc}
\hline Intensity of erosive esophagitis & CagA-positive & CagA-negative & Total \\
\hline Grade A* & 15 & 9 & $24(86 \%)$ \\
Grade B* & 3 & 1 & $4(14 \%)$ \\
Total & $18(64 \%)$ & $10(36 \%)$ & $28 / 148(19 \%)$ \\
\hline
\end{tabular}

Fifteen patients had erosive esophagitis grade A (Los Angeles classification ${ }^{(20)}$ ) and were $C a g A$-positive, while nine patients were $C a g \mathrm{~A}$-negative. Of the remaining four patients with grade B erosive esophagitis, three were CagA-positive, while one was CagA-negative. Statistical analysis showed no significant correlation between CagA-positive strains and the grade of esophagitis (Table 4). No statistically significant correlations were found between the groups of patients with and without erosive esophagitis and CagA-positive status either in the gastric corpus or antrum (Table 5).

TABLE 4. CagA status according to gastric site of colonization in patients with erosive esophagitis

\begin{tabular}{lcc}
\hline Gastric site & CagA-positive & CagA-negative \\
\hline Corpus & $18(64 \%)$ & $10(36 \%)$ \\
Antrum & $21(75 \%)$ & $7(25 \%)$ \\
\hline
\end{tabular}

$P=0.38$

TABLE 5. CagA-positive and erosive esophagitis status in gastric sites

\begin{tabular}{lccc}
\hline Gastric site & $\begin{array}{c}\text { With erosive } \\
\text { esophagitis }\end{array}$ & $\begin{array}{c}\text { Without erosive } \\
\text { esophagitis }\end{array}$ & Total \\
\hline Corpus & $18 / 28$ & $73 / 120$ & $91 / 148$ \\
Antrum & $21 / 28$ & $82 / 120$ & $103 / 148$ \\
\hline$P=0.91$ & & &
\end{tabular}

\section{DISCUSSION}

The first authors who described the influence of $H$. pylori in the pathophysiology of GERD in patients with peptic ulcer were LABENZ et al. ${ }^{(17)}$. This study had great impact in medical literature, being the first to show a greater incidence of erosive esophagitis in duodenal ulcer patients who had their $H$. pylori eradicated $(25.8 \%)$, compared to the group that remained $H$. pylori positive $(12.9 \%)$. After that, a new study that analyzed eight double-blind prospective trials comprising 1,165 patients with duodenal ulcer disease (940 active, 225 past history) added further support to the theory that eradication of $H$. pylori in duodenal ulcer patients does not lead to reflux disease. It was verified the development of erosive esophagitis in 24 (4\%) of 621 healed patients versus $14(3 \%)$ of 544 with persistent $H$. pylori ${ }^{(19)}$. In this study, final endoscopies were done 4-30 weeks after therapy completion, differently from our patients who passed through endoscopies 3 months and 1 year after eradication.

KUPCINSKAS et al. ${ }^{(16)}$ also followed patients with duodenal ulcer for 1 year after $H$. pylori eradication and have not observed any increase in reflux esophagitis incidence, either. Other studies, obtained similar data in patients with gastric ulcers $^{(12)}$.

The present study included patients predominantly with duodenal ulcers $(71.6 \%)$. We verified the development of erosive esophagitis in $19 \%$ of them after $H$. pylori eradication, similarly to RAGHUNATH et al. ${ }^{(34)}$ systematic review publication.

A previous reflux disease hidden by peptic ulcer disease ${ }^{(28)}$, population differences ${ }^{(9)}$ and methodological differences can justify these conflicting results. 
The most aggressive strains, for example those expressing the cytotoxin-associated gene A $(\operatorname{Cag} \mathrm{A})$, have been more frequently linked to pathologies associated with this bacterium (peptic ulcer disease, MALT gastric lymphoma, gastric adenocarcinoma)

In our study, the analysis of $H$. pylori-infected gastric mucosal samples taken from the corpus and antrum revealed no statistically significant difference in the predominance of the CagA gene among patients who developed erosive esophagitis, suggesting that despite the high predominance of this gene in both groups. This was expected since is already known the association of peptic ulcer disease and Cag- $A$ strains.

Several studies made evident that the virulence of the CagA-positive H. pylori strains can determine a protector effect against the development of reflux esophagitis, especially that more severe ${ }^{(18,39)}$, including Barrett's esophagus ${ }^{(37)}$.

In Brazil, PEREIRA-LIMA et al. ${ }^{(31)}$ concluded that $H$. pylori gastric infection and especially $H$. pylori CagA-positive may play a protective role against the development of the most severe forms of GERD. On the other hand in this study, the patients had dyspepsia, peptic ulcer and erosive gastritis, differently that our study, in which all patients homogeneously had peptic ulcer disease. However, KILTZ et al. ${ }^{(13)}$ did not observe the development of reflux esophagitis for those cured of the H. pylori infection, even if infected by CagA-positive strains. Another Brazilian study, by QUEIROZ et al. ${ }^{(32)}$ has provided evidence supporting the independent protective roles of CagA-positive $H$. pylori strains and the degree of corpus gastritis against GERD. When the CagA genotypes were analyzed, no statistically significant differences were found among the samples collected from the corpus and those from the antrum.

The present study was the first to analyze whether $H$. pylori genotype and its site in the stomach affect progression to erosive esophagitis 1 year after eradication of the infection in patients with peptic ulcer.

\section{CONCLUSION}

One year after eradication of Helicobacter pylori in patients with peptic ulcers, erosive esophagitis developed in almost one-fifth of the patients. The cytotoxin-associated gene A (CagA) carried by some $H$. pylori strains had no effect on whether the patient developed esophagitis or not, irrespective of the site of infection in the stomach.

Batista CAG, Silva FM, Barbutti RC, Eisig JN, Mattar R, Navarro-Rodriguez T. O genótipo e o local no estômago de isolamento do Helicobacter pylori em pacientes com úlcera péptica não são fatores preditivos para o desenvolvimento de esofagite erosiva 1 ano após a erradicação da bactéria. Arq Gastroenterol. 2009;46(3):204-8.

RESUMO - Contexto - É controverso se a infecção pelo Helicobacter pylori é um fator de proteção ou de predisposição para o desenvolvimento da doença de refluxo gastroesofágico. Cepas mais virulentas tais como as que expressam a citotoxina CagA e o local no estômago de infecção pela bactéria, podem estar correlacionados com a prevenção ou desenvolvimento de esofagite. Objetivos - Determinar a incidência de esofagite erosiva após a erradicação do H. pylori em pacientes com úlcera péptica e a sua associação com a virulência das cepas da bactéria e o local no estômago de seu isolamento. Métodos - Um tratamento tríplice com lansoprazol, amoxicilina e claritromicina foi administrado a 159 pacientes com úlcera péptica. Endoscopia digestiva alta, exame histológico, teste rápido da urease e o teste respiratório de uréia com carbono-14 foram realizados antes, 3 meses e 1 ano após o tratamento. A genotipagem das cepas do H. pylori por meio de PCR foi realizada separadamente em amostras obtidas da mucosa do corpo e do antro gástricos. Resultados - Um ano após o tratamento, 148 pacientes curados da infecção foram avaliados: 28 (19\%) apresentavam esofagite erosiva, 24 com grau A da classificação de Los Angeles e 4 com grau B. Nas amostras obtidas da mucosa do corpo gástrico, a citotoxina CagA foi positiva em 18 (64\%) pacientes com esofagite erosiva, enquanto que nas amostras obtidas do antro gástrico, a citotoxina CagA foi positiva em 21 (75\%). Conclusões - A incidência de esofagite erosiva em pacientes com doença péptico-ulcerosa foi de 19\%. Não houve correlação entre o local de isolamento no estômago ou as cepas CagA-positivas do H. pylori e a proteção ou o desenvolvimento de esofagite erosiva, em pacientes com úlcera péptica, 1 ano depois da erradicação da bactéria.

DESCRITORES - Helicobacter pylori. Úlcera péptica. Esofagite. 


\section{REFERENCES}

1. Befrits R, Sjostedt S, Odman B, Sorngard H, Lindberg G. Curing Helicobacter pylori infection in patients with duodenal ulcer does not provoke gastroesophageal reflux disease. Helicobacter. 2000;5:202-5.

2. Blanchard TG, Drakes ML, Czinn S. Helicobacter infection: pathogenesis. Curr Opin Gastroenterol. 2004;20:10-5.

3. Cabral MM, Oliveira CA, Mendes CM, Guerra J, Queiroz DM, Rocha GA, Rocha AM, Nogueira AM. Gastric epithelial cell proliferation and CagA status in Helicobacter pylori gastritis at different gastric sites. Scand J Gastroenterol. 2007;42:545-54.

4. Covacci A, Censini S, Bugnoli M, Petracca R, Burroni D, Macchia G, Massone A, Papini E, Xiang Z, Figura N, Rappuoli R. Molecular characterization of the $128 \mathrm{kDa}$ immunodominant antigen of Helicobacter pylori associated with cytotoxicity and duodenal ulcer. Proc Natl Acad Sci USA. 1993;90:5791-5.

5. Cremonini F, Di Caro S, Delgado-Aros S, Sepulveda A, Gasbarrini G, Gasbarrini A Camilleri M. Meta-analysis: the relationship between Helicobacter pylori infection and gastro-oesophageal reflux disease. Aliment Pharmacol Ther. 2003;18:279-89.

6. Everhart JE. Recent developments in the epidemiology of Helicobacter pylori. Gastroenterol Clin North Am. 2000;29:559-78.

7. Falk GW. The possible role of Helicobacter pylori in GERD. Semin Gastrointest Dis. 2001;12:186-95.

8. Fallone CA, Barkun AN, Friedman G, Best L, Joseph L. Is Helicobacter pylor eradication associated with gastroesophageal reflux disease? Am J Gastroenterol. 2000;95:914-20.

9. Hamada H, Haruma K, Mihara M, Kamada T, Yoshihara M, Sumii K, Kajiyama G, Kawanishi M. High incidence of reflux oesophagitis after eradication therapy for Helicobacter pylori: impacts of hiatal hernia and corpus gastritis. Aliment Pharmacol Ther. 2000;14:729-35.Hammar M, Tyszkiewicz T, Wadström T, O'Toole PW. Rapid detection of Helicobacter pylori in gastric biopsy material by polymerase chain reaction. J Clin Microbiol. 1992;30:54-8.

10. Hou W, Schubert ML. Gastric secretion. Curr Opin Gastroenterol. 2006;22:593-8

11. Jonaitis L, Kiudelis G, Kupcinskas L. Gastroesophageal reflux disease after Helicobacter pylori eradication in gastric ulcer patients: a one-year follow-up study. Medicina (Kaunas). 2008;44:211-5.

12. Kiltz U, Pfaffenbach B, Schmidt WE, Adamek RJ. The lack of influence of CagA positive Helicobacter pylori strains on gastro-oesophageal reflux disease. Eur J Gastroenterol Hepatol. 2002;14:979-84.

13. Koike T, Ohara S, Sekine H, Iijima K, Abe Y, Kato K, Toyota T, Shimosegawa T. Helicobacter pylori infection prevents erosive reflux oesophagitis by decreasing gastric acid secretion. Gut. 2001;49:330-4

14. Kuipers EJ, Thijs JC, Festen HP. The prevalence of Helicobacter pylori in peptic ulcer disease. Aliment Pharmacol Ther. 1995;9(Suppl 2):59-69.

15. Kupcinskas L, Jonaitis L, Kiudelis G. A 1 year follow-up study of the consequence of Helicobacter pylori eradication in duodenal ulcer patients: unchanged frequency of erosive oesophagitis and decreased prevalence of non-erosive gastro-oesophageal reflux disease. Eur J Gastroenterol Hepatol. 2004;16:369-74.

16. Labenz J, Blum AL, Bayerdörffer E, Meining A, Stolte M, Borsch G. Curing Helicobacter pylori infection in patients with duodenal ulcer may provoke reflux esophagitis. Gastroenterology. 1997;112:1442-7.

17. Lai CH, Poon SK, Chen YC, Chang CS, Wang WC. Lower prevalence of Helicobacter pylori infection with vacAs1a, cagA-positive and babA2-positive genotype in erosive reflux esophagitis disease. Helicobacter. 2005;10:577-85.

18. Laine L, Sugg J. Effect of Helicobacter pylori eradication on development of erosive esophagitis and gastroesophageal reflux disease symptoms: a post hoc analysis of eight double blind prospective studies. Am J Gastroenterol. 2002;97:2992-7.

19. Lundell LR, Dent J, Bennett JR, Blum AL, Armonstrong D, Galmiche JP, Johnson F, Hongo M, Richter JE, Spechler SJ, Tytgat GN, Wallin L. Endoscopic assessment of oesophagitis: clinical and functional correlates and further validation of the Los Angeles classification. Gut. 1999;45:172-80.

20. Malaty HM, Graham DY. Importance of childhood socioeconomic status on the current prevalence of Helicobacter pylori infection. Gut. 1994;35:742-5.

21. Mattar R, Silva FM, Alexandrino AM, Laudanna AA. Validation of ${ }^{14} \mathrm{C}$-urea breath test for diagnosis of Helicobacter pylori. Rev Inst Med Trop Sao Paulo. 1999;41:3-7.

22. Mattar R, Laudanna AA. Helicobacter pylori genotyping from positive CLOtests in patients with duodenal ulcer. Rev Hosp Clin Fac Med Sao Paulo. 2000;55:155-60.

23. McColl KE, Dickson A, El-Nujumi A, El Omar E, Kelman A. Symptomatic benefit 1-3 years after $H$. pylori eradication in ulcer patients: impact of gastroesophageal reflux disease. Am J Gastroenterol. 2000;95:101-5.

24. McColl KE. Motion-Helicobacter pylori causes or worsens GERD: arguments against the motion. Can J Gastroenterol. 2002;16:615-7.

25. Miller SA, Dykes DD, Polesky HF. A simple salting out procedure for extracting DNA from human nucleated cells. Nucleic Acids Res. 1988;16:1215.

26. Moraes-Filho JPP, Chinzon D, Eisig JN, Hashimoto CL, Zaterka S. Prevalence of heartburn and gastroesophageal reflux disease in the urban Brazilian population. Arq Gastroenterol. 2005;42:122-7.

27. O'Connor HJ, McGee C, Ghabasch NM, Cunnane K. Prevalence of esophagitis in $H$. pylori-positive peptic ulcer disease and the impact of eradication therapy. Hepatogastroenterology. 2001;48:1064-8.

28. O'Morain CA, Qasim A. Motion--Helicobacter pylori worsens GERD: arguments for the motion. Can J Gastroenterol. 2002;16:611-4.

29. Peek RM, Blaser MJ. Pathophysiology of Helicobacter pylori-induced gastritis and peptic ulcer disease. Am J Med. 1997;102:200-7.

30. Pereira-Lima JC, Marques DL, Pereira-Lima LF, Hornos AP, Rotas C. The role of cagA Helicobacter pylori strains in gastro-esophageal reflux disease. Eur J Gastroenterol Hepatol. 2004;16:643-7.

31. Queiroz DM, Rocha GA, Oliveira CA, Rocha AM, Santos A, Cabral MM, Nogueira AM. Role of corpus gastritis and CagA-positive Helicobacter pylori infection in reflux esophagitis. J Clin Microbiol. 2002;40:2849-53.

32. Radosz-Komoniewska H, Bek T, Jozwiak J, Martirosian G. Pathogenicity of Helicobacter pylori infection. Clin Microbiol Infect. 2005;11:602-10.

33. Raghunath AS, Hungin AP, Woof D, Childs S. Systematic review: the effect of Helicobacter pylori and its eradication on gastro-oesophageal reflux disease in patients with duodenal ulcers or reflux oesophagitis. Aliment Pharmacol Ther. 2004;20:733-44.

34. Shirota T, Kusano M, Kawamura O, Horikoshi T, Mori M, Sekiguchi T. Helicobacter pylori infection correlates with severity of reflux esophagitis: with manometry findings. J Gastroenterol. 1999;34:553-9.

35. Tefera S, Hatlebakk JG, Berstad AE, Berstad A. Eradication of Helicobacter pylori does not increase acid reflux in patients with mild to moderate reflux oesophagitis. Scand J Gastroenterol. 2002;37:877-83.

36. Vaezi MF, Falk GW, Peek RM, Vicari JJ, Goldblum JR, Perez-Perez GI, Rice TW, Blaser MJ, Ritcher JE. CagA-positive strains of Helicobacter pylori may protect against Barrett's esophagus. Am J Gastroenterol. 2000;95:2206-11.

37. Vakil N, Hahn B, McSorley D. Recurrent symptoms and gastro-oesophageal reflux disease in patients with duodenal ulcer treated for Helicobacter pylori infection. Aliment Pharmacol Ther. 2000;14:45-51.

38. Vicari JJ, Peek RM, Falk GW, Goldblum JR, Easley KA, Schnell J, Perez-Perez GI, Halter SA, Rice TW, Blaser MJ, Ritcher JE. The seroprevalence of CagApositive Helicobacter pylori strains in the spectrum of gastroesophageal reflux disease. Gastroenterology. 1998;115:50-7.

39. Webb PM, Knight T, Greaves S, Wilson A, Newell DG, Elder J, Forman D. Relation between infection with Helicobacter pylori and living conditions in childhood evidence for person to person transmission in early life. BMJ. 1994;308:750-3.

40. Werdmuller BF, Loffeld RJ. Helicobacter pylori infection has no role in the pathogenesis of reflux esophagitis. Dig Dis Sci. 1997;42:103-5.

41. Wu JC, Sung JJ, Ng EK, Go MY, Chan WB, Chan FK, Leung WK, Choi CL, Chung SC. Prevalence and distribution of Helicobacter pylori in gastroesophageal reflux disease: a study from the East. Am J Gastroenterol. 1999;94 1790-4.

42. Zaterka S, Eisig JN, Chinzon D, Rothstein W. Factors related to Helicobacter pylori prevalence in an adult population in Brazil. Helicobacter. 2007;12:82-8.

43. Zentilin P, Iiritano E, Vignale C, Bilardi C, Mele MR, Spaggiari P, Gambaro C, Dulbecco C, Tessiere L, Riglione S, Mansi C, Mastracci L, Vigneri S, Fiocca R, Savarino V. Helicobacter pylori infection is not involved in the pathogenesis of either erosive or non-erosive gastro-oesophageal reflux disease. Aliment Pharmaco Ther. 2003;17:1057-64

Recebido em 10/7/2008 Aprovado em $7 / 1 / 2009$ 